\title{
The heme oxygenase-1 and c-FLIP in acute myeloid leukemias: two non-redundant but mutually exclusive cellular safeguards protecting cells against TNF-induced cell death?
}

\author{
S. Shirley ${ }^{1}$ and 0 . Micheau ${ }^{1,2}$ \\ ${ }^{1}$ INSERM, U866, Dijon, F-21079 France ; Faculty of Medicine and Pharmacy, Univ. Bourgogne, Dijon, F-21079 France \\ ${ }^{2}$ Centre Georges-François Leclerc, Dijon, F-21000 France
}

Correspondence to: O. Micheau, e-mail: : omicheav@u-bourgogne.fr

Commentary on: Rushworth et al .Oncotarget: this issue

Received: September 16, 2010, Accepted: September 16, 2010,

Published: September 16, 2010

Copyright: @ Shirley et al This is an open-access article distributed under the terms of the Creative Commons Attribution License, which permits unrestricted use, distribution, and reproduction in any medium, provided the original author and source are credited

TNF-induced apoptosis is tightly regulated by the $\mathrm{NF}-\kappa \mathrm{B}$ pathway. Under physiologic conditions, $\mathrm{TNF} \alpha$ stimulation induces NF- $\kappa \mathrm{B}$ activation and cell survival, due to the regulation of anti-apoptotic genes, including c-FLIP, a caspase- 8 inhibitor, whose expression is sufficient to protect cells against TNF-induced apoptosis. TNF triggers cell death only in circumstances where the $\mathrm{NF}-\kappa \mathrm{B}$ pathway is defective. Rushworth and collaborators have recently demonstrated, however, that the heme oxygenase-1 (HO-1), also known as Heat shock protein
32 (Hsp32) [1], like c-FLIP, can afford protection against TNF-induced cell death in AML cells, despite NF- $\kappa B$ inactivation [2]. They now provide evidence that TNF mediated HO-1 up-regulation, is negatively regulated by c-FLIP, revealing a novel negative regulatory feedback loop controlling apoptosis induced by TNRI (Figure 1).

In contrast to Fas or TRAIL receptor-mediated cell death, apoptosis induced by TNFRI is a two-step process that requires the formation of two sequential signalling complexes [3]. The plasma membrane-bound complex I, including TNFR1, TRADD, RIP1 and TRAF2, is

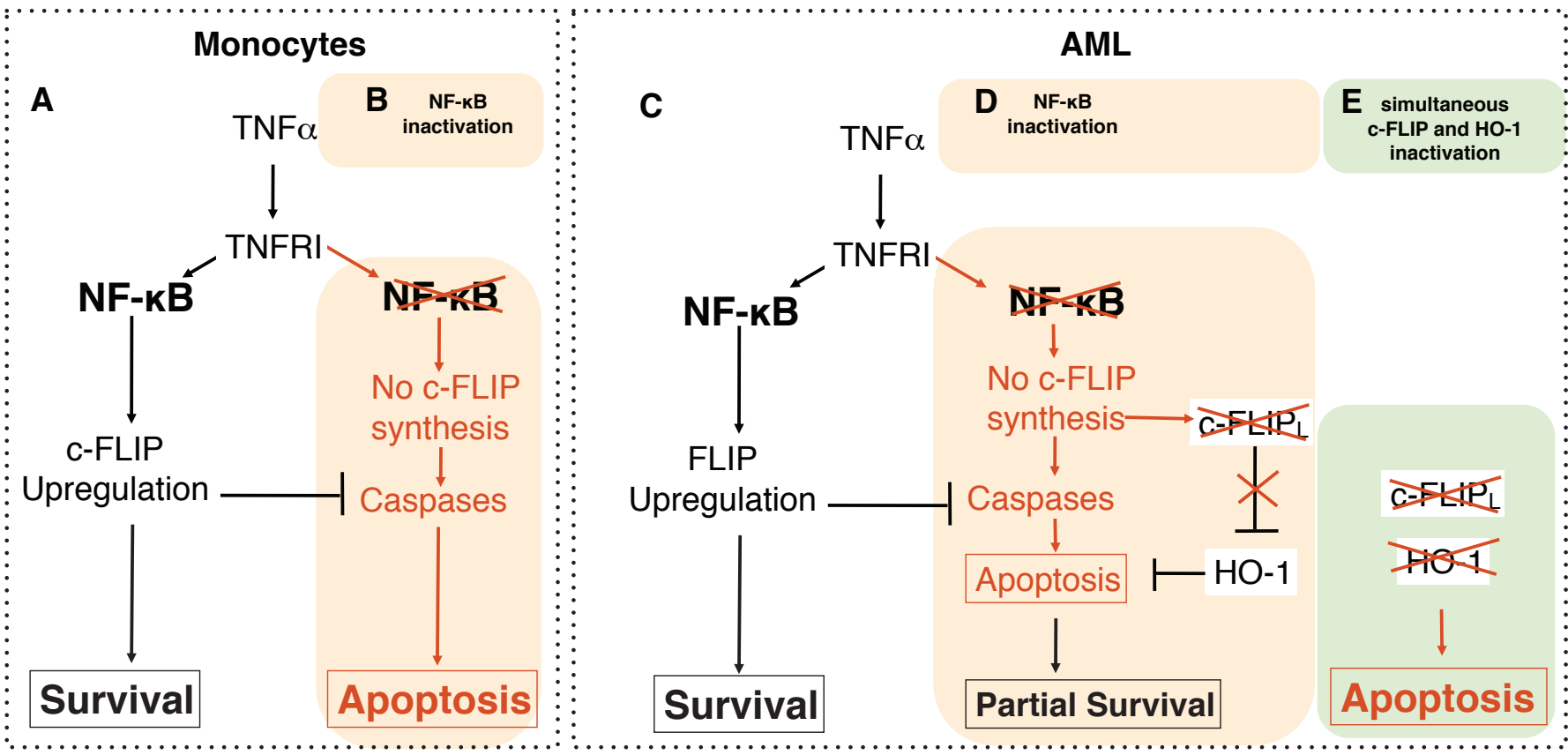

Figure 1: Contribution of HO-1 and c-FLIPL to the regulation of TNF signalling in monocytes and acute myeloid leukemia cells (AML). (A) In monocytes, engagement of TNFR1 by TNF $\alpha$ induces activation of NF- $\mathrm{B}$, leading to up-regulation of FLIP and inhibition of cell death, however inactivation of NF- $\mathrm{BB}(\mathrm{B})$ prevents FLIP neosynthesis, allowing caspase activation and apoptosis. (C) AML cells are resistant to TNF $\alpha$-induced apoptosis, even upon inactivation of NF- $\kappa B$ (D), due to the up-regulation of HO-1. (E) Simultaneous inactivation of c-FLIP and HO-1 enhances TNF-induced cell death. 
dedicated to the activation of the survival pathway NF$\kappa \mathrm{B}$. FADD and caspase- 8 are recruited in the "cytosolic" complex, also coined complex II, which is devoid of TNFRI, triggering caspase- 8 activation and apoptosis [3]. In the vast majority of cells, however, activation of NF$\kappa \mathrm{B}$ induces protection against TNF-induced cell death [4]. Several anti-apoptotic genes are regulated by NF- $\mathrm{B}[5]$, but so far only c-FLIP has been demonstrated to afford full protection when expressed alone [6,7]. Activation of complex II and thus triggering of the apoptotic program is generally thought to occur in NF- $\mathrm{BB}$ defective cells due to the lack of c-FLIP supply [8].

HO-1 is a stress-related anti-apoptotic molecule that has been implicated in enhanced survival of cancer cells and in drug-resistance [1]. Overexpression of HO-1 protects cells from $\mathrm{H} 2 \mathrm{O} 2-$, Fas- or TNF-induced apoptosis [9-11]. Unlike HO-2, the second evolutionary conserved heme oxygenase isoenzyme, HO-1 is not expressed constitutively. HO-1 is generally induced under oxidative stress enabling enhanced free heme catabolism and inhibition of programmed cell death[1]. HO-1 mediated cytoprotection has been assigned to the heme catabolism sub-product $\mathrm{Fe}^{2+}$, which triggers reactive oxygen species (ROS) production and NF- $\mathrm{B}$ activation [12]. Induced expression of HO-1 by IL-1 and TNF $\alpha$ was suggested to involve protein kinase c, calcium and phospholipase A2 [13]. Activation of the $\mathrm{PkB} / \mathrm{Akt}$ pathway and induction of Nrf2 were shown to induce HO-1 up-regulation upon $\mathrm{H} 2 \mathrm{O} 2$ stimulation[9]. More recently it was shown that TNF-mediated ROS production, in NF- $\kappa \mathrm{B}$ inactivated AML cells, induced the activation of the transcription factor Nrf2 leading to HO-1 up-regulation [2]. The cytoprotective activity of HO-1 in endothelial cells was demonstrated to require NF- $\kappa \mathrm{B}$ activation by $\mathrm{TNF} \alpha$ [14]. Interestingly, HO-1-mediated inhibition of TNFRI-induced apoptosis, in NF- $\kappa \mathrm{B}$ defective cells, can be restored by the ectopic expression of some NF- $\kappa \mathrm{B}$ regulated genes such as c-IAP2, A1 or A20 [14]. Furthermore, HO-1-mediated protection against TNF-induced cell death is not restricted to tumour cells, as endothelial cells or human fibroblasts induced to express HO-1 fail to undergo apoptosis [14,15].

Remarkably, and in contrast to most studies demonstrating that inhibition of the $N F-\kappa B$ pathway restores TNF-induced cell death in normal and cancer cells, Rushworth et al. demonstrate in this issue that NF- $\kappa$ B inhibition only affords partial restoration of apoptosis in AML cells, due to the up-regulation of HO-1. Accordingly, inactivation of $\mathrm{c}-\mathrm{FLIP}_{\mathrm{L}}$ expression was sufficient to trigger the accumulation of HO-1 in the absence of TNF, though apoptosis following $\mathrm{TNF} \alpha$ stimulation was only partially restored. Accordingly, inactivation of $c-F_{L} P_{L}$ expression in these cells, albeit partially restoring $\mathrm{TNF} \alpha-$ induced apoptosis, in the absence of TNF, triggered the accumulation of HO-1. However, simultaneous inactivation of c-FLIP ${ }_{\mathrm{L}}$ and $\mathrm{HO}-1$ significantly enhanced AML cell sensitivity to TNF $\alpha$. Rushworth et al. make the critical observation that induction of $\mathrm{HO}-1$ expression is negatively regulated at the steady state by c-FLIP ${ }_{L}$, but not the short forms of c-FLIP, providing a plausible explanation for the resistance of AML cells to TNFinduced apoptosis, despite inactivation of the $N F-\kappa B$ pathway.

These results demonstrate that $\mathrm{HO}-1$ exerts cytoprotection in AML cells, irrespective of $\mathrm{NF}-\kappa \mathrm{B}$ activation, and suggest in addition that $\mathrm{HO}-1$ and c-FLIP $\mathrm{L}_{\mathrm{L}}$ may negatively regulate TNF-induced cell death in a nonredundant, but exclusive manner. Of particular interest, c-FLIP $_{\mathrm{L}}$ down-regulation was unable to promote $\mathrm{HO}-1$ expression in monocytes. Thus the markedly increased expression of $\mathrm{c}-\mathrm{FLIP}_{\mathrm{L}}$ and the constitutive activation of $\mathrm{NF}-\kappa \mathrm{B}$ in erythroleukemia cells [16] would support the proposal that negative regulation of HO-1 expression by $\mathrm{c}-F L I P_{\mathrm{L}}$, at the basal level, might require sustained NF$\kappa \mathrm{B}$ activation. In line with this hypothesis, it has been demonstrated in the past that over-expression of c-FLIP, or at least its amino acid terminal portion, could induce NF$\kappa \mathrm{B}$ activation [17-20]. It is not clear, however, whether $\mathrm{NF}-\kappa \mathrm{B}$ activation alone is sufficient to repress HO-1. ROS production, through the activation of $\mathrm{Nrf} 2$, may also induce the restoration of HO-1 expression in cells in which c-FLIP ${ }_{L}$ has been inactivated, as c-FLIP downregulation was shown to induce ROS production in some tumour cells [21], while its over-expression produces the opposite effect [22].

While it is clear that the molecular mechanisms underlying c-FLIP ${ }_{\mathrm{L}}$-mediated $\mathrm{HO}-1$ repression at the basal level needs to be explored more precisely, the possibility that HO-1 itself may regulate c-FLIP expression, through its ability to inhibit NF- $\mathrm{B}$ activation, or to induce ROS remains an open question. In line with this hypothesis, it has recently been demonstrated that $\mathrm{HO}-1$ was able to impair NF- $\kappa \mathrm{B}$ nuclear translocation in cardiomyocytes [23] and that ROS production can trigger the degradation of c-FLIP in an ubiquitylation-dependent manner [24]. Mutual regulation of these cellular "safeguards" would thus certainly be beneficial for tumour cells to maintain a high level of protection against TNF-induced killing. Altogether these findings uncover a novel cell-decision regulatory mechanism controlling cell death signalling induced by TNFRI, which may extend to other deathinducing ligands of the TNF family.

\section{ACKNOWLEDGMENTS}

This work is supported by grants of the Conseil Regional de Bourgogne, the INCa (Institut National du Cancer), Cancéropôle Grand-Est, ANR (Agence Nationale de la Recherche, ANR-06-JCJC-0103 and 07-PCV-0031), and the European Community (ApopTrain Marie Curie RTN). Sarah Shirley is supported by a fellowship from the INCa (Polynom174). 


\section{REFERENCES}

1. Gozzelino R, Jeney V, Soares MP. Mechanisms of cell protection by heme oxygenase-1. Annu Rev Pharmacol Toxicol 2010; 50:323-354.

2. Rushworth SA, MacEwan DJ. HO-1 underlies resistance of AML cells to TNF-induced apoptosis. Blood 2008; 111:3793-3801.

3. Micheau O, Tschopp J. Induction of TNF receptor I-mediated apoptosis via two sequential signaling complexes. Cell 2003; 114:181-190.

4. Beg AA, Baltimore D. An essential role for NF-kappaB in preventing TNF-alpha-induced cell death. Science 1996; 274:782-784.

5. Wang CY, Mayo MW, Korneluk RG, Goeddel DV, Baldwin AS, Jr. NF-kappaB antiapoptosis: induction of TRAF1 and TRAF2 and c-IAP1 and c-IAP2 to suppress caspase-8 activation. Science 1998; 281:1680-1683.

6. Micheau O, Lens S, Gaide O, Alevizopoulos K, Tschopp J. NF-kappaB signals induce the expression of c-FLIP. Mol Cell Biol 2001; 21:5299-5305.

7. Kreuz S, Siegmund D, Scheurich P, Wajant H. NF-kappaB inducers upregulate cFLIP, a cycloheximide-sensitive inhibitor of death receptor signaling. Mol Cell Biol 2001; 21:3964-3973.

8. Micheau O. Cellular FLICE-inhibitory protein: an attractive therapeutic target? Expert Opin Ther Targets 2003; 7:559573.

9. Brunt KR, Fenrich KK, Kiani G, Tse MY, Pang SC, et al. Protection of human vascular smooth muscle cells from $\mathrm{H} 2 \mathrm{O} 2$-induced apoptosis through functional codependence between HO-1 and AKT. Arterioscler Thromb Vasc Biol 2006; 26:2027-2034.

10. Kushida T, LiVolti G, Goodman AI, Abraham NG. TNFalpha-mediated cell death is attenuated by retrovirus delivery of human heme oxygenase-1 gene into human microvessel endothelial cells. Transplant Proc 2002; 34:2973-2978.

11. Pileggi A, Cattan P, Berney T, Molano RD, Vizzardelli $\mathrm{C}$, et al. HO-1 upregulation protects the pancreatic cell line betaTC3 from cytokines and Fas-induced apoptosis. Transplant Proc 2001; 33:266-267.

12. Choi BM, Pae HO, Jeong YR, Oh GS, Jun CD, et al. Overexpression of heme oxygenase (HO)-1 renders Jurkat $\mathrm{T}$ cells resistant to fas-mediated apoptosis: involvement of iron released by HO-1. Free Radic Biol Med 2004; 36:858871.

13. Terry CM, Clikeman JA, Hoidal JR, Callahan KS. TNFalpha and IL-1alpha induce heme oxygenase-1 via protein kinase $\mathrm{C}, \mathrm{Ca} 2+$, and phospholipase A2 in endothelial cells. Am J Physiol 1999; 276:H1493-1501.

14. Brouard S, Berberat PO, Tobiasch E, Seldon MP, Bach FH, et al. Heme oxygenase-1-derived carbon monoxide requires the activation of transcription factor NF-kappa B to protect endothelial cells from tumor necrosis factor-alpha-mediated apoptosis. J Biol Chem 2002; 277:17950-17961.

15. Petrache I, Otterbein LE, Alam J, Wiegand GW, Choi AM. Heme oxygenase-1 inhibits TNF-alpha-induced apoptosis in cultured fibroblasts. Am J Physiol Lung Cell Mol Physiol 2000; 278:L312-319.

16. Rae C, Langa S, Tucker SJ, MacEwan DJ. Elevated NFkappaB responses and FLIP levels in leukemic but not normal lymphocytes: reduction by salicylate allows TNF-induced apoptosis. Proc Natl Acad Sci U S A 2007; 104:12790-12795.

17. Kataoka T, Tschopp J. N-terminal fragment of c-FLIP(L) processed by caspase 8 specifically interacts with TRAF2 and induces activation of the NF-kappaB signaling pathway. Mol Cell Biol 2004; 24:2627-2636.

18. Kataoka T, Budd RC, Holler N, Thome M, Martinon F, et al. The caspase- 8 inhibitor FLIP promotes activation of NF-kappaB and Erk signaling pathways. Curr Biol 2000; 10:640-648.

19. Golks A, Brenner D, Krammer PH, Lavrik IN. The c-FLIP$\mathrm{NH} 2$ terminus (p22-FLIP) induces NF-kappaB activation. J Exp Med 2006; 203:1295-1305.

20. Bannerman DD, Eiting KT, Winn RK, Harlan JM. FLICElike inhibitory protein (FLIP) protects against apoptosis and suppresses NF-kappaB activation induced by bacterial lipopolysaccharide. Am J Pathol 2004; 165:1423-1431.

21. Nakajima A, Kojima Y, Nakayama M, Yagita H, Okumura $\mathrm{K}$, et al. Downregulation of c-FLIP promotes caspasedependent JNK activation and reactive oxygen species accumulation in tumor cells. Oncogene 2008; 27:76-84.

22. Shim E, Lee YS, Kim HY, Jeoung D. Down-regulation of c-FLIP increases reactive oxygen species, induces phosphorylation of serine/threonine kinase Akt, and impairs motility of cancer cells. Biotechnol Lett 2007; 29:141-147.

23. Yeh $\mathrm{CH}$, Chen TP, Wang YC, Lin YM, Lin PJ. HO-1 activation can attenuate cardiomyocytic apoptosis via inhibition of NF-kappaB and AP-1 translocation following cardiac global ischemia and reperfusion. J Surg Res 2009; 155:147-156.

24. Wang L, Azad N, Kongkaneramit L, Chen F, Lu Y, et al. The Fas death signaling pathway connecting reactive oxygen species generation and FLICE inhibitory protein down-regulation. J Immunol 2008; 180:3072-3080. 